\title{
KEMAMPUAN KONSEP BILANGAN DAN BERCERITA PADA ANAK KELOMPOK A MELALUI PEMBELAJARAN CONTEXTUAL TEACHING AND LEARNING (CTL) DI TK BAITUL ILMI PANJANG JIWO SURABAYA
}

\author{
Susi Maulida a, 1 \\ ${ }^{\text {a }}$ STITNU Al Hikmah Mojokerto \\ ${ }^{1}$ maulida4455@gmail.com
}

\begin{tabular}{l}
\hline Informasi artikel \\
\hline Received : \\
Agust 15, 2019. \\
Revised : \\
Agust 27, 2019. \\
Publish : \\
September 09, 2019. \\
\\
Kata kunci: \\
Contextual Teaching \\
and Learning; \\
Kemampuan \\
Bercerita; \\
Kognitif;
\end{tabular}

Keywords:

Contextual Teaching

and Learning;

Storytelling;

Cognitive;

\begin{abstract}
ABSTRAK
Penelitian ini bertujuan untuk menguji pengaruh model pembelajaran Contextual Teaching and Learning (CTL) dalam kemampuan bercerita dan konsep bilangan. Pendekatan penelitian yang digunakan adalah penelitian kuantitatif dengan model penelitian eksperimental, dimana peneliti memberikan perlakukan atau treatment berupa pembelajaran dengan menggunakan CTL dan melakukan observasi dalam kegiatan pembelajaran anak di kelas serta melakukan pengukuran sebelum dan sesudah pemberian treatment. Berdasarkan hasil analisa adalah dapat disimpulan terdapat peningkatan yang signifikan terhadap kemampuan bercerita dengan menggunakan pendekatan CTL sebesar 9.18> 7.82. Sedangkan untuk konsep bilangan juga terdapat peningkatan yang signifikan sebesar $18.0909>13.2273$.
\end{abstract}

This work is licensed under a Creative Commons Attribution-ShareAlike 4.0 International License. Allows readers to read, download, copy, distribute, print, search, or link to the full texts of its articles and allow readers to use them for any other lawful purpose. 


\section{PENDAHULUAN}

Pendidikan Anak Usia Dini (PAUD) adalah menyiapkan anak-anak akan konsepsi dasar kognitif, psikomotorik, dan pembentukan sikap. Persoalan tersebut dicoba diatasi dengan penerapan suatu paradigma baru dalam pembelajaran di kelas, diantaranya adalah pembelajaran kontekstual. Pembelajaran kontekstual adalah terjemahan dari Contextual Teaching and Learning (CTL) dapat diartikan sebagai suatu pembelajaran yang berhubungan dengan suasana tertentu, (Johnson \& Johnson: 2002). Pendekatan CTL merupakan konsep belajar yang bermakna mengaitkan antara materi yang diajarkan dengan situasi dunia nyata anak dan mendorong antara pengetahuan yang dimiliknya dengan penerapannya dalam kehidupan anak sebagai anggota keluarga dan masyarakat.

CTL menawarkan jalan menuju keunggulan akademis yang dapat diikuti oleh semua siswa. Hal ini bisa terjadi karena CTL sesuai dengan cara kerja otak dan prinsip-prinsip yang menyokong sistem kehidupan. Penemuan-penemuan terbaru dalam ilmu pengetahuan modern tentang otak, dan prinsip-prinsip dasar tertentu yang menyokong semua sistem kehidupan dan keseluruhan alam semesta, menjadi dasar bagi pembelajaran dan pengajaran kontekstual. Aspek-aspek perkembangan yang harus dirangsang salah satunya adalah aspek kognitif. Aspek perkembangan kognitif penting untuk dikembangkan karena mempunyai tujuan mengembangkan kemampuan anak sehingga dapat menemukan berbagai alternatif pemecahan masalah, membantu anak untuk mengembangkan kemampuan logika matematika dan pengetahuan akan ruang dan waktu (Depdiknas, 2007).

Kognitif disinonimkan dengan intelektual, karena proses intelektual akan berhubungan dengan konsep yang telah dimiliki oleh anak dan berkaitan dengan bagaimana anak menggunakan kemampuan berpikirnya dalam memecahkan 
persoalan. Pemikiran anak usia 4 sampai 7 tahun berkembang sangat pesat secara bertahap kearah konseptualisasi. Menurut Montessori (Sudono, 1995; Suparno, 2001), dengan bermain anak memiliki kemampuan untuk memahami konsep dan pengertian secara alamiah tanpa paksaan seperti konsep bilangan dan konsep warna. Dimana cara dalam meningkatkan pemahaman konsep bilangan pada anak usia dini khususnya pada anak TK dengan melalui CTL. Pembelajaran CTL dapat mengaitkan materi pembelajaran dengan kehidupan yang nyata pada anak-anak.

Pembelajaran CTL dalam konsep bilangan dapat sekaligus memberikan informasi atau menghasilkan pengertian, memberi kesenangan serta mengembangkan imajinasi anak, selain itu dapat juga dengan menggunakan metoda yang bervariasi. Dengan demikian untuk menarik konsep dan minat serta perhatian anak terhadap konsep bilangan maka hendaknya daya pembelajaran yang disajikan sedemikian rupa agar efektif dan menyenangkan.

Penyebab lain yang melatarbelakangi adalah kemampuan mengenal konsep bilangan (misalnya: menyebut, menghitung dan menujuk serta mengelompokkan) masih rendah hal ini disebabkan karena metode pembelajaran di sekolah yang sering menggunakan lembar kerja (LKA). Aktivitas anak hanya mengerjakan lembar kerja yang berisi pengembangan kognitif tentang membilang, menghitung, menghubungkan angka dengan huruf, menebali angka dan mencocokkan bilangan dengan lambang bilangan. Hal tersebut mengakibatkan anak belum bisa memahami sepenuhnya tentang konsep bilangan dan kemampuan kognitif anak tidak akan berkembang secara optimal. Adanya kesulitan yang dihadapi oleh anak tersebut berdampak pada hasil belajar tidak dicapai secara optimal. 
Berdasarkan pengalaman lapangan, hasil belajar yang ideal akan dicapai secara optimal apabila pembelajaran berbekal pendekatan dan metode yang relevan, namun demikian jika proses pembelajaran didukung oleh pembelajaran CTL sangat mungkin sehingga pembelajaran yang disampaikan menarik, dan inovatif. Pembelajaran CTL jika dikiatkan dengan lingkup perkembangan bahasa akan lebih bermakna dan memiliki arti. Makna yang dimaksudkan adalah dapat menumbuhkan minat belajar anak. Minat itu akan tumbuh jika anak melihat kenyataan secara langsung, bukan dari informasi yang didapat. Anak usia dini, khususnya usia 4-5 tahun dapat mengembangkan kosa kata secara mengagumkan. Owens (dalam Kurnia, 2009) mengemukakan bahwa "anak usia tersebut memperkaya kosa katanya melalui pengulangan". Mereka sering mengulangi kosa kata yang baru dan unik sekalipun belum memahami artinya. Mengembangkan kosa kata tersebut, anak menggunakan fast wrapping yaitu suatu proses dimana anak menyerap arti kata baru setelah mendengarnya sekali atau dua kali dalam dialog. Pada masa dini inilah anak mulai mengkombinasikan suku kata menjadi kata, dan kata menjadi kalimat.

Anak usia dini dipersiapkan untuk mengenal beberapa kata, simbol-simbol huruf dalam pembelajaran dengan menggunakan pembelajaran CTL. Pembelajaran CTL ini tergolong masih baru dalam lembaga (TK) karena sebelumnya di TK menggunakan pembelajaran tradisional. Berdasarkan kondisi faktual di lapangan pembelajaran ini relevan dan sesuai untuk diimplementasikan menggunakan CTL sebagai pembelajaran yang mulanya tradisional berganti ke CTL. Pembelajaran CTL sangat cocok di terapkan di TK khususnya pada aspek perkembangan bahasa dan kognitif. CTL akan lebih bermakna, jika anak mengalami sendiri apa yang dipelajarinya, bukan mengetahuinya dari orang lain. Rumusan masalah dalam 
penelitian ini adalah Adakah pengaruh CTL terhadap kemampuan bercerita dan konsep bilangan anak kelompok A di TK Baitul Ilmi Panjang Jiwo Surabaya dengan tujuan dari penelitian ini adalah untuk mengetahui pengaruh pembelajaran CTL terhadap kemampuan bercerita dan konsep bilangan anak kelompok A di TK Baitul Ilmi Panjang Jiwo Surabaya.

\section{METODE}

Pendekatan penelitian yang digunakan adalah penelitian kuantitatif dengan model penelitian eksperimental. Penelitian dilakukan dengan menggunakan desain atau rancangan eksperimen model Quasi Ekperimental, dimana desain ini mempunyai kelompok kontrol tetapi tidak dapat berfungsi sepenuhnya untuk mengontrol variabel-variabel luar yang mempengaruhi pelaksanaan eksperimen.

Pada penelitian eksperimen ini, peneliti membagi dua kelompok yaitu, kelompok eksperimen dan kelompok kontrol. Kedua kelompok ini memilki sifat dan karakteristik yang sama atau mendekati sama. Pada kelompok eksperimen diberikan treatment dengan CTL, sedangkan dalam kelompok kontrol dalam pembelajaran tradisional. Selanjutnya, proses penelitian diobservasi untuk menentukan perbedaan yang terjadi pada kelompok eksperimen.

Teknik analisis data dalam penelitian kuantitatif menggunakan statistik, baik statistik deskriptif maupun statistik inferensial. Pada penelitian ini, statistik dekriptif digunaan untuk mendekripsikan variabel kemampuan mengenal konsep bilangan dan kemampuan bercerita kelompok A di TK.

Teknik analisis data yang digunakan untuk mengolah data kuantitatif yang berupa angka-angka menggunakan analisis statistik uji-t (paired t-test). Analisis 
statistik ini digunakan untuk mengetahui ada tidaknya perbedaan kemampuan pengenalan konsep bilangan dan kemampuan kosa kata antara sebelum (pretest) dan sesudah (posttest) mendapatkan perlakukan (treatment) berupa pembelajaran dengan menggunakan CTL.

\section{PEMBAHASAN}

Hasil penelitian menunjukkan bahwa ada perbedaan konsep bilangan antara sebelum (pretest) dan sesudah (posttest) mendapatkan CTL pada kelompok eksperimen. Jadi dapat dikatakan ada pengaruh yang signifikan penggunaan pembelajaran CTL terhadap konsep bilangananak yaitu pada kemampuan konsep bilangan.

Berdasarkan tabel 2 hasil uji beda dengan Paired t test, didapatkan nilai Sig. Sebesar 0.000 yang mana nilai ini lebih kecil dari 0.05, maka tolak H1 dan terima H0 yang berarti ada perbedaan kognitif (konsep bilangan) antara sebelum (pretest) dan sesudah (posttest) mendapatkan CTL pada kelompok eksperimen. Sedangkan pada kelompok kontrol, didapatkan nilai Sig. Sebesar 0.178 yang mana nilai ini lebih besar dari 0.05 , maka terima $\mathrm{H} 1$ dan tolak $\mathrm{H} 0$ yang berarti tidak ada perbedaan kognitif (konsep bilangan) antara sebelum (pretest) dan sesudah (posttest) mendapatkan CTL.

Perkembangan kognitif mengacu pada perkembangan anak dalam hal berpikir dan kemampuan untuk memberikan suatu alasan dimana kognitif adalah suatu proses berpikir, yaitu kemampuan individu untuk menghubungkan, menilai dan mempertimbangkan suatu kejadian atau peristiwa. 
Hasil penelitian menunjukkan ada perbedaan konsep bilangan antara sebelum (pretest) dan sesudah (posttest) mendapatkan CTL, dimana konsep bilangansesudah diberi pembelajaran CTL lebih tinggi daripada konsep bilangansebelum diberi pembelajaran CTL. Hal ini berarti pembelajaran CTL sangat dibutuhkan pada konsep bilangantentang membilang banyak benda, mengenal, menunjukkan lambang bilangan, menghitung benda, mengelompokkan benda.

Hal tersebut juga diperkuat dengan beberapa jurnal penelitian oleh pendapat Luh Wina (2016) menjelaskan bahwa pembelajaran CTL dikaitkan dengan perkembangan kognitif dan konsep bilangan pada kelompok A berpengaruh positif terhadap pembelajaran di kelas, seperti pendapat Ni made (2014) juga menjelaskan bahwa pembelajaran CTL dapat meningkatkan perkembangan kognitif anak di kelas.

Berdasarkan pendapat para peneliti di atas dapat dipaparkan bahwa pembelajaran CTL dalam konsep bilangan dapat meningkatkan pembelajaran anak di dalam kelas.

\section{Pengaruh CTL Terhadap Kemampuan Bercerita}

Hasil penelitian menunjukkan bahwa ada perbedaan kemampuan bercerita antara sebelum (pretest) dan sesudah (posttest) mendapatkan CTL pada kelompok eksperimen. Jadi dapat dikatakan ada pengaruh yang signifikan penggunaan pembelajaran CTL terhadap perkembangan bahasa siswa yaitu pada kemampuan bercerita dengan dasar perkembangan utama bahasa.

Berdasarkan tabel 4 hasil uji beda dengan Paired t test, didapatkan nilai Sig. Sebesar 0.005yang mana nilai ini lebih kecildari 0.05 , maka tolak H1 dan terima H0 yang berarti ada perbedaan kemampuan bercerita antara sebelum (pretest) dan sesudah (posttest) mendapatkan CTL pada kelompok eksperimen. Sedangkan pada 
kelompok kontrol, didapatkan nilai Sig. Sebesar 0.206 yang mana nilai ini lebih besar dari 0.05 , maka terima $\mathrm{H} 1$ dan tolak $\mathrm{H} 0$ yang berarti ada perbedaan kemampuan bercerita antara sebelum (pretest) dan sesudah (posttest) mendapatkan CTL pada kelompok kontrol.

Hasil penelitian menunjukkan ada perbedaan kemampuan bercerita antara sebelum (pretest) dan sesudah (posttest) mendapatkan CTL, dimana kemampuan bercerita sesudah diberi pembelajaran CTL lebih tinggi daripada kemampuan bercerita sebelum diberi pembelajaran CTL. Hal ini berarti pembelajaran CTL sangat dibutuhkan pada mata pelajaran bahasa tentang menyebutkan kata yang dilambangkannya dalam simbol-simbol, menyusun kalimat, dan melengkapi kalimat yang tepat dengan kata.

Hal tersebut juga diperkuat dengan jurnal penelitian oleh Septyani Windi Utami (2010) yang menjelaskan bahwa terdapat pengaruh pada kemampuan bercerita dalam proses pembelajaran perkembangan bahasa di kelas. Hal ini sejalan dengan pendapat Rahmatul (2016) kemampuan bercerita dalam perkembangan bahasa dapat ditingkatkan dengan menggunakan pembelajaran CTL.

Dari beberapa pendapat di atas dapat dipaparkan bahwa pembelajaran CTL dalam kemampuan bercerita dapat meningkatkan pembelajaran perkembangan bahasa anak di kelas.

\section{KESIMPULAN}

Berdasarkan hasil analisa pada bab sebelumnya dapat ditarik kesimpulan bahwa: (1) Terdapat pengaruh CTL terhadap perkembangan kognitif (konsep bilangan) kelompok A di TK Baitul Ilmi Panjang Jiwo Surabaya. Hal ini diketahui dari 
adanyaperbedaan kognitif(konsep bilangan) antara sebelum (pretest) dan sesudah (posttest) mendapatkan CTL pada kelompok eksperimen. Dengan demikian hipotesis pertama penelitian yang menyatakan "Ada pengaruh CTL terhadap perkembangan kognitif kelompok A di TK Baitul Ilmi Panjang Jiwo Surabaya” terbukti kebenarannya. Perkembangan kognitif (konsep bilangan) sesudah diberi pembelajaran CTL lebih tinggi daripada kognitif (konsep bilangan) sebelum diberi pembelajaran CTL; (2) Terdapat pengaruh CTL terhadap perkembangan bahasa (kemampuan bercerita) kelompok A di TK Baitul Ilmi Panjang Jiwo Surabaya. Hal ini diketahui dari adanya perbedaan kemampuan bercerita antara sebelum (pretest) dan sesudah (posttest) mendapatkan CTL pada kelompok eksperimen. Dengan demikian hipotesis kedua penelitian yang menyatakan "Ada pengaruh CTL terhadap perkembangan bahasa kelompok A di TK Baitul Ilmi Panjang Jiwo Surabaya" terbukti kebenarannya. Kemampuan bercerita sesudah diberi pembelajaran model CTL lebih besar daripada kemampuan bercerita sebelum diberi pembelajaran model CTL. 


\section{REFERENSI}

Depdiknas. (2007). Pedoman Pengembangan Fisik/Motorik di Taman Kanak-kanak. Jakarta

Johnson, David W and Roger T. Johnson. 2002. Cooperative Learning Methode: A Meta-Analysis. Journal of Research in Education.

Johnson, Elaine B. 2002. Contextual Teaching \& Learning Menjadikan Kegiatan Belajar-Mengajar Mengasyikkan dan Bermakna. Bandung: MLC

Kementrian Pendidikan Nasional, 2010, Pendidikan Karakter Teori dan Praktek, Direktorat Jenderal Manajemen Pendidikan Dasar dan Menengah

Komalasari, Kokom. 2010. Pembelajaran Kontekstual: Konsep dan Aplikasi. Refika Aditama. Bandung

Mansur. 2005. Pendidikan Anak Usia Dini Dalam Islam. Yogyakarta: Pustaka Pelajar

Nurhadi, dkk. (2002). Pembelajaran Kontekstual (Cooperatif Learning di Ruangruang Kelas). Jakarta: Gramedia Widiasarana

Rita kurnia. 2009. Metodologi pengembangan bahasa anak usia dini. Pekanbaru: Cendikia insani.

Santrock, John W. 2009. Perkembangan Anak. Edisi 11. Jakarta. Erlangga

Semiawan, Conny. 2000. Belajar Dan Penberdayaan Dalam Taraf Pendidikan Usia Dini (Pendidikan Prasekolah Dan Sekolah Dasar). Jakarta: PT Gramedia Widia Sarana

Sudono, Anggani. (1995). Alat Permainan dan Sumber Belajar. Jakarta: Depdikbud Dirjen Dikti

Sujiono, Yuliani Nurani \& Sujiono, Bambang. 2013. Bermain Kreatif Berbasis Kecerdasan Jamak. Jakarta: PT Indeks

Sujiono, Yuliani nurani dan Bambang Sujiono. (2010). Bermain Kreatif Berbasis Kecerdasan Jamak. Jakarta: PT Indeks

Sukardi. 2012. Metodologi Penelitian Pendidikan. Jakarta: Bumi Aksara

Suryanto. 2002. Penggunaan masalah kontekstual dalam pembelajaran Fisika. Makalah disajikan pada pidato pengukuhan guru besar Universitas Negeri Yogyakarta.

Suyadi. 2009. Permainan Edukatif yang Mencerdaskan. Jogjakarta: Powerbook 